INDEPENDENT JOURNAL OF MANAGEMENT \& PRODUCTION (IJM\&P)

http://www.ijmp.jor.br

v. 12, n. 1, January-February 2021

ISSN: 2236-269X

DOI: 10.14807/ijmp.v12i1.773

\title{
THE EFFECT OF CORPORATE GOVERNANCE AND FINANCIAL LEVERAGE ON EFFICIENCY OF PAKISTAN TEXTILE SECTOR
}

\author{
Seema Chandani \\ Institute of Business Management, Pakistan \\ E-mail: snaushad.chandani@gmail.com \\ Nawaz Ahmed \\ Institute of Business Management, Pakistan \\ E-mail: nawaz.ahmad@iobm.edu.pk
}

Submission: $1 / 4 / 2018$

Revision: 3/23/2018

Accept: 5/12/2020

\section{ABSTRACT}

This research observes the effect of corporate governance and financial leverage on the efficiency of listed companies in Pakistan. The variables return on assets and return on equity are chosen as the firm's efficiency of the textile sector for this research. Measures of corporate governance used are board size, director's remuneration, and Audit committee members, whereas financial leverage is used as a control variable. The data of corporate governance, financial leverage, and efficiency variable are composed of annual reports of the top ten listed textile companies from Karachi stock exchange. The research consists of the period from 2012 to 2017. Panel data is used to examine four hypotheses and to test the significance of corporate governance and financial leverage on a firm's performance the OLS regression models are applied. The finding of this study revealed that board size, audit committee, director's remuneration is positively correlated with a firm's performance ROA and ROE, and conversely, financial leverage is negatively correlated with a firm's performance. Overall regression result of this study discovered that the audit committee members and financial leverage are statistically insignificant, whereas board size and director's remuneration are statistically positive significant. This concludes that there is no significant association between corporate governance and firm's performance as well as financial leverage with the firm's performance. The sample size of this study was small and this research is limited to the textile sector of Pakistan. 
DOI: 10.14807/ijmp.v12i1.773

Future researchers may have included more determinants of corporate governance such as women on board, board meeting, family ownership structure, etc.

Keywords: Audit committee members, Board size, Corporate governance, Director's remuneration, Financial leverage

\section{INTRODUCTION}

\subsection{Background of the Study}

Corporate governance and financial leverage are essential components that could contribute information about how to enhance the shareholder's value. Corporate governance is the arrangement of guidelines, rules, processes and procedures and institutions which affect the way a corporation is controlled and directed (Khatab et al., 2011). Another researcher argued that in corporate governance set up organizational manager are accessible of all kind of information than shareholders, whereas, shareholders are concerned about profit in shape of dividend, however, the objective of managers is different as they are interested such as secure their job, get promotions with increments, etc. (Jensen \& Meckling, 1976).

Gill and Mathur (2011) explored that properly applied corporate governance is essential for all business firms to achieve organizational goals for both developed and developing countries. Resilient corporate governance is an important element of business firms in developing countries like Pakistan for globalization purposes (Achchuthan \& Rajendran, 2013). Strong corporate governance includes responsibility, independence, accountability and transparency principles which enhance the firm performance. Corporate governance not only upgrades the company's performance, likewise increases the profitability of the company (Nur’ainy et al., 2013).

The textile sector plays an important role and working strongly to improve the Pakistan economy. This study conducts to explore the performance of the textile industry and describe how corporate governance and financial leverage influence organization performance from the period of 2012 to 2016 as the textile industry is a core industry in Pakistan. Some elements are used to measure corporate governance that comprises board size, director's remuneration, Audit committee members and financial leverage are used as a control variable, however, return on assets and return on equity are employed to measure the firm's performance. The remaining paper is designed in this way: Part II: delivers a description of prevailing literature on the topic. Part III: detail explanation of methodology and variables developed in the 
DOI: 10.14807/ijmp.v12i1.773

research paper. Part IV: explains the discussion of empirical outcomes. Last part V: briefly concludes and recommends further research.

The objective of this research is to discover the influence of corporate governance and financial leverage on the performance of the top 10 Pakistani listed textile companies. Likewise, this paper also attempts to explain the association between corporate governance and leverage with a business's performance. The main objective of this study is to examine both the corporate governance system and financial leverage impact on organization performance.

The answer to the above-stated question could be a positive or negative impact on the company's performance. Shareholders are only interested to gain maximum return against their investment. Therefore, this study is conducted to examine how corporate governance mechanisms and financial leverage impact on organization performance.

\subsection{Research Question}

How corporate governance and financial leverage impact the efficiency of the Pakistan textile industry?

\section{LITERATURE REVIEW}

\subsection{Overview of Corporate Governance:}

An efficient corporate governance system supports to resolve the agency matters. Shareholders make certain that their shares in the shape of investment are being consumed and invested prudently in cost-effective and productive settings. Corporate governance is a strong component for the improvement and betterment of the organization's performance as well as the economic growth of the country. Below are the details of the observed and practical work on the association among corporate governance, financial leverage and company's efficiency in both advanced/established and emerging nations.

Accurately implemented corporate governance standards in the company may enhance a firm's performance in terms of profitability and growth, it also improves credibility, competitiveness and develops good relations with employees, customers, business partners, shareholders, etc. (Todorovic, 2013). The researcher also examined that if the organization firmly follows the corporate governance principles then the company's financial position will be strong in terms of net profit margin and earning per share.

If we talk about the implementation of corporate governance in Pakistan, this is initiated late by the Securities and Exchange Commission (SECP) in 2002. Though to expand and 
DOI: 10.14807/ijmp.v12i1.773

develop further practices and application of corporate governance SECP has established an association of corporate governance in 2004. In Pakistan corporate governance is still in progress of practicing and is far behind inappropriate execution due to several reasons.

\subsection{Board Size and organization performance}

As explored by Dalton \& Dalton (2005) that the satisfactory position of bigger board size is the more mutual aggregate information that the board subsequently has and thus, bigger board size will prompt better execution. Furthermore, the board has the duty to observe, correct and expel incapable management people, to secure that the management staff observe the interests of investors.

Raheja, (2005) that internal are a significant basis of firm-explicit information for the board, however, they may have misshaped goals because of private advantages and shortage of independence from the CEO. As compare with insiders, outsiders are increasingly free, giving better observing, yet are less educated about the company's accomplishments.

Once more, the benefit of bigger board size and an expanding quantity of non-executive directors is the more mutual aggregate information controlled by the board, which is moreover important for the observing capacity. Consequently, both capacities foresee an underlying development in board execution as enhancement in board size, and rises in the quantity of nonexecutives are relied upon to have a positive influence than enhances in the quantity of executive directors (Patro et al., 2003).

Previous papers about board size and their impact on the company's productivity deliver mixed findings. The researcher observed the board size and their impact on organization productivity, therefore for this purpose researcher took an immense sample of 2746 listed companies as board size is measured through the board of directors present in the board, (Guest, 2009) examined the robust negative association amongst board size and organization performance.

This empirical study supports the claim that huge board size weakens and creates problems in decision making and communication between the board of directors. Further results also propose that large firms have a strong negative connection between board size and the company's effectiveness. One more study was done to inspect the influence of board size on bank productivity, by using the regression model, the study has shown that an impact of board size on bank efficiency was negative (Tahir et al., 2014).

\subsection{Director's Remuneration and organization performance}


DOI: $10.14807 /$ ijmp.v12i1.773

Nahar Abdullah (2006) examined the association between corporate governance, the company's performance and director's remuneration in the Malaysian organization and research explored that the association amongst director's pay and return on assets was negative. Conversely, comparative research amongst director's compensation and organizations efficiency was done in UK and Poland, the research empirically examined the significant positive association amongst director's pay and company's size, research also showed the positive relationship among return on capital and directors remunerations (Herdan \& Szczepańska, 2011).

A study by (Main, 1993) examined a strong positive association amongst board remuneration and organization performance. Contrary a research conducted on china by and Wen et al., (2002) and observed that there was a negative insignificant association among executive remuneration and company's financial performance. Another study explored the nonappearance of the remuneration committee causing the directors to write and sign their contract by themselves.

However, in corporate governance, the remuneration committee is an important function and never be consider as an organizational system for inspection of the progress in the director's compensation, nevertheless, this is a forum that regarded as a significant strategy of the compensation preparation for directors (Williamson, 1985).

\subsection{Audit Committee and organization performance}

In the corporate governance structure, the Audit committee plays an essential and critical role. Financial anomalies in the previous few years arisen an interrogation in numerous companies about the integrity, reliability, and honesty of the business reporting practices, procedures and protection between the characteristics of auditors, financial specialists, controllers, financial counselors, and the management.

Subsequently in 2001 and 2002 USA has explored an unexpected wave of large financial firms involved in fraudulent activities involving companies such as WorldCom and Enron, after that there was the requirement of efficient audit committee establishment. In most of these dishonors cases, managers first think about their benefits which causes the demolition and devastation of the wealth of shareholders. According to (Coffee Jr, 2005) auditors play an essential part in protecting the wealth of shareholders and stopping the happenings of these dishonor scandals. 
According to the American Bar Association (ABA 1978), a committee that conducts less meeting at least two meetings per year is less expected to carry out their responsibilities attentively. The audit committee should work effectively and efficiently and the purpose of the audit committee is to closely check, monitor, and control the financial requirements and activities of executive management (Kalbers \& Fogarty, 1993).

\subsection{Financial Leverage and organization performance:}

One of the researchers studied the components of corporate governance for instance; female on board members, CEO and chairman duality, experience and payment of board and research observed that all elements were emphatically affected on the company's execution. (Tahir et al., 2014) has done the research to inspected the effect of corporate governance and company execution and employed ROE and ROA as an independent variable whereas the dependent variable was Tobin's $\mathrm{Q}$ and result shown that growth and leverage have a strong positive association with ROA and Tobin's Q.

Rashid (2008) conducted the comparison study between developed and developing countries and had come with information that corporate governance plays balanced and identical part in increasing the firms performance in both developed and developing countries and researcher also observed that there is minor difference among the association of corporate governance and companies executive regarding budgetary market of both developed and developing nations.

This difference may be due to the change in the structure of corporate governance because of the diverse law and order situation and social-economic conditions of the specific nation. Likewise, the researcher in this study discovered that corporate governance is constructive for the effective utilization of assets to improve the firm's performance. It has also been explored that financial markets of developed nations considered the small board size and financial markets of developing countries considered large board size.

It has been demonstrated that there is a positive and significant association amongst leverage and director stock proprietorship recommending that managers whose financial benefits are all the more determinedly lined up with external investors will pursue after more levered capital structure to expand the worth of the firm (Berger et al., 1997). It has been revealed that a positive statistically significant association amongst managerial possession and leverage proposing that share proprietorship gives managers a motivator to build the company's leverage (Mehran, 1992). 
DOI: 10.14807/ijmp.v12i1.773

\subsection{Theoretical background}

\subsubsection{Agency Theory:}

The Agency Theory defines the agency association that a party, the head (The Company) assigns some task to subsequent party, the agent (Directors). With regards to companies and problems of corporate control and mechanism, Agency Theory understands corporate governance tools similar to a fundamental checking method in guaranteeing that any issues that might be carried by principal and agent associations are reduced.

Agency Theory is the most prevailing theoretical structure in corporate governance examination. Hence, Agency Theory is a significant arrangement of suggestions in the company's financial aspects discipline. The theory is established on the presumption that when the ownership is isolated from the control of a large company, the manager is performing as an agent for the benefit of the owner-principal is inclined to making moral risks, for example, avoiding and seizing wealth to the payment of the principal.

Thus, the theory proposes that the principal forms suitable motivating force components to discourage the agent from treating such conduct accordingly, from the view purpose of investors, the agency point of view on the Board structure is related with making independent Boards (Eisenhardt, 1989; Jensen \& Meckling, 1979; Hermalin \& Weisbach, 2001).

\subsubsection{Resource dependency Theory:}

The Resource Dependency Theory is the outcome of studies on Board structure by sociologists who have concentrated on the researches of interconnecting directorates and their suggestion on the institutional and cultural force. It has its inceptions in the open framework hypothesis in that capacity associations have a differing level of dependence on the external condition, especially for the funds and resources they require to work.

Ambiguity and dependency boost the companies to actively deal with the atmosphere and the impact is on funds related activities and client results when a circumstantial factor, high organization influence is taken into deliberation. Corporate Board is perceived as intends to oversee external dependency, decrease environmental ambiguity and exchange costs related to the environmental dependency. The impact of this is to improve and develop the overall proficiency of the companies and decrease funds (Pfeffer \& Salancik, 2003; Abid et al., 2015; Romano, 1996).

\subsection{Conceptual framework}


ISSN: 2236-269X

DOI: 10.14807/ijmp.v12i1.773

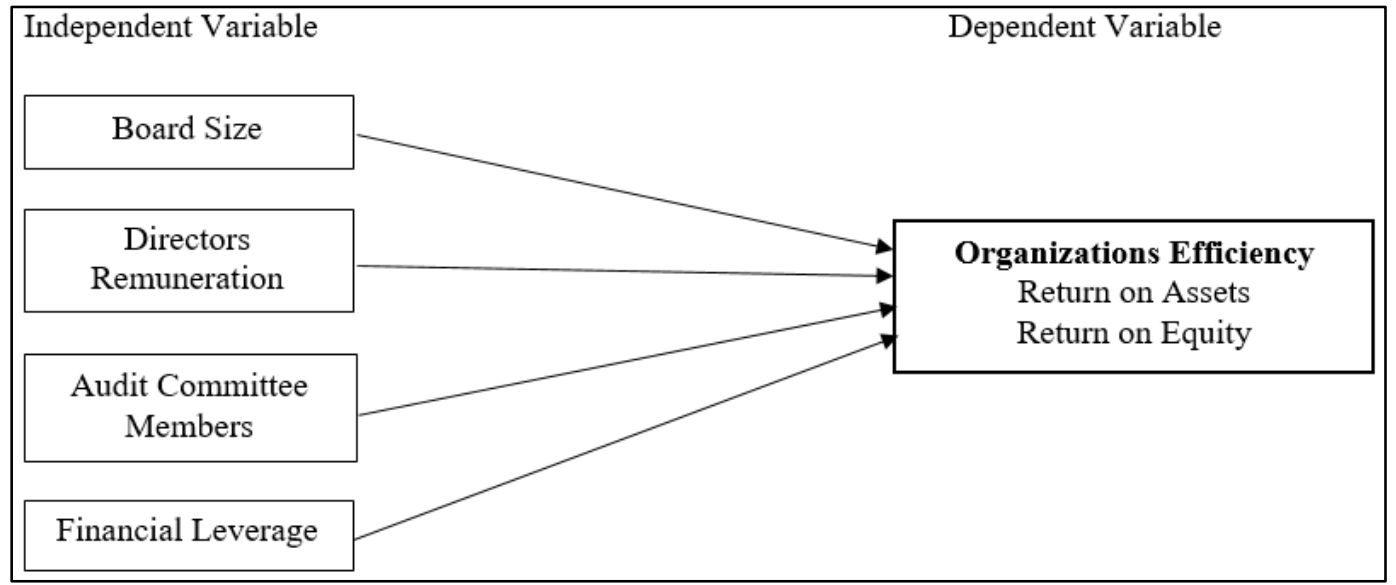

Figure 1: Independent/dependent variable

In light of the above literature review, we came up with the following constructs, three independent variables for instance board size, director's compensation and audit committee members, these are the elements of corporate governance. A dependent variable consists of two constructs i.e. return on assets and return on equity which demonstrates the efficiency of the Pakistan textile sector. We have taken financial leverage as a control variable to measure the firm’s performance.

\subsection{Hypotheses}

- H1: Association amongst board size and firm performance is significant.

- H2: Association amongst the director's remuneration and organization performance is significant.

- H3: There is a significant association amongst the audit committee and the company's efficiency

- H4: Relationship amongst financial leverage and the company's performance is significant.

\section{METHODOLOGY}

\subsection{Sample Size and Data Collection}

The panel and secondary data is utilized in this research paper and the information of data was collected from the financial annual reports of Textile Company's website of 10 listed textile firms of Pakistan for the period of five years from 2012 to 2016 in Appendix I. All textile firms are listed in Karachi Stock Exchange (KSE).

\subsection{Variables}


DOI: $10.14807 /$ ijmp.v12i1.773

This research assesses the association amongst corporate governance and financial leverage on textile sector performance. Two dependent variables for instance return on assets and return on equity is utilized to evaluate the performance of textile firms. However, corporate governance elements such as board size, director's remuneration, and Audit committee members are used as an independent variable. Financial leverage used as a control variable.

\subsection{Model Specification}

- Model A

TROAit $=\alpha 0+\beta 1$ BSizeit $+\beta 2$ DRemit $+\beta 3$ ACMit $+\beta 4$ Leverageit + eit

- Model B

TROEit $=\alpha 0+\beta 1$ BSizeit $+\beta 2$ DRemit $+\beta 3$ ACMit $+\beta 4$ Leverageit + eit

Table 1: Definition of Variables

\begin{tabular}{ll}
\hline Variable & Definition \\
\hline TROA & TROA ratio is computed by dividing net income and average total assets. \\
TROE & TROE ratio is computed by dividing net income by shareholder's equity. \\
BSIZE & Total number of board of directors \\
DRem & Total director remuneration \\
ACM & Total audit committee members \\
Leverage & Financial leverage is computed by dividing total liability and total assets \\
A & Intercept Coefficient \\
B & Coefficient of Slope \\
E & Error Term \\
I & 1 to 10 textile firms \\
$\mathrm{T}$ & 2012 to 2016 \\
\hline
\end{tabular}

Table 2: Descriptive Statistics

\begin{tabular}{|c|c|c|c|c|c|c|c|}
\hline & ACM & BSIZE & & & GE & ROA & ROE \\
\hline Mean & & 3.0166 & 7.3000 & 20.012909 & 0.5165 & 0.0531 & 0.1035 \\
\hline Maximum & & 4.0000 & 9.0000 & 97330000 & 2.6100 & 0.2500 & 0.4263 \\
\hline Minimum & & 2.0000 & 6.0000 & 23240000 & 0.0068 & 0.0007 & -0.0479 \\
\hline Std. Dev. & & 0.469 & 0.6457 & 22585496 & 0.6223 & 0.0545 & 0.0824 \\
\hline Observations & & 60 & 60 & 60 & 60 & 60 & 60 \\
\hline
\end{tabular}

Table 2 demonstrates the analysis of a descriptive analysis of 60 observations with a sample of 10 textile companies in Pakistan. This table consists of mean, standard deviation, maximum and minimum values of all dependent and independent variables. The table explains that the average board size is 7.30 as the maximum members on the board were 9 and the minimum is 6 in a board of textile companies. 
DOI: $10.14807 /$ ijmp.v12i1.773

This table also illustrates that the average audit committee members setting in the board is 3. The average of director's remuneration is 20 Million, in which the maximum remuneration of directors is 97.33 Million and the minimum is 23.24 Million. Return on assets and return on equity are employed to measure the performance of textile firms, the average of ROA and ROE is 0.0531 and 0.1035 respectively, whereas the standard deviation of ROA and ROE is 0.0545 and 0.0824 respectively.

Table 3: Correlation of all variables

\begin{tabular}{lrrrrrr}
\hline & ROA & \multicolumn{1}{c}{ ROE } & BSIZE & ACM & DREM & LEVERAGE \\
\hline ROA & 1.000 & & & & & \\
ROE & 0.694 & 1.000 & & & & \\
BSIZE & 0.116 & 0.112 & 1.000 & & & \\
ACM & 0.041 & 0.017 & -0.073 & 1.000 & 1.000 & \\
DREM & 0.303 & 0.149 & 0.003 & 0.231 & -0.101 & 1.000 \\
LEVERAGE & -0.102 & -0.181 & -0.063 & 0.004 & \\
\hline
\end{tabular}

Table 2 indicates the relationships through correlation. This table shows the audit committee and board size, Leverage and ROA are inversely correlated with each other. However, ROE and ROA, Board size with ROA and ROE, audit committee with ROA and ROE, director's remuneration with ROA, ROE, board size and audit committee are positively correlated. Leverage is positively correlated with only ACM, whereas leverage is negatively correlated with ROA, ROE, BSize, and DRem.

Return on assets and return on equity have the strongest relationship. The weakest correlation is between leverage and BSize. The overall result indicates that board size, audit committee, director's remuneration is positively correlated with the firm's performance ROA and ROE, and on the other side financial leverage is negatively correlated with the firm's performance.

Table 4: Regression Analysis - Model A

Dependent Variable: ROA

Method: Panel Least Squares

\begin{tabular}{ccrrr}
\hline \hline Variable & Coefficient & Std. Error & t-Statistic & Prob. \\
\hline \hline C & -0.019014 & 0.094234 & -0.201774 & 0.8408 \\
ACM & -0.002324 & 0.015245 & -0.152427 & 0.8794 \\
BSIZE & 0.009260 & 0.010793 & 0.857953 & 0.0946 \\
DREM & $7.27 \mathrm{E}-10$ & $3.17 \mathrm{E}-10$ & 2.289521 & 0.0259 \\
LEVERAGE & -0.005652 & 0.011228 & -0.503348 & 0.6167 \\
\hline \hline
\end{tabular}

Table 4 shows that the Audit Committee and leverage are inversely associated with the company's performance with return on assets, therefore hypotheses (H3 and H4) are not accepted. Board size is positive and significantly associated with firm performance with return 
DOI: 10.14807/ijmp.v12i1.773

on assets, thus hypothesis (H1) is accepted. This table also indicates that the director's remuneration has positive and significantly relative with the performance of the textile sector of Pakistan, hence the hypothesis (H2) is accepted. Audit committee and leverage are statistically insignificant, whereas board size and director's remuneration are statistically significant.

Table 5: Regression Analysis - Model B

Dependent Variable: ROE

Method: Panel Least Squares

\begin{tabular}{crrrr}
\hline \hline Variable & Coefficient & Std. Error & t-Statistic & Prob. \\
\hline \hline C & 0.013953 & 0.146391 & 0.095317 & 0.9244 \\
ACM & -0.001127 & 0.023682 & -0.047582 & 0.9622 \\
BSIZE & 0.012909 & 0.016767 & 0.769923 & 0.0446 \\
DREM & $4.90 \mathrm{E}-10$ & $4.93 E-10$ & 0.994218 & 0.0245 \\
LEVERAGE & -0.021331 & 0.017443 & -1.222928 & 0.2266 \\
\hline
\end{tabular}

Table 5 shows that the Audit Committee and leverage are inversely insignificant related to the company's performance ROE, therefore hypotheses (H3 and H4) are not accepted. Board size is positive significant associated with firm performance, thus hypothesis (H1) is accepted. The table also indicates that the director's remuneration has a positive significant impact on the performance of the textile sector of Pakistan, hence the hypothesis (H2) is accepted. Audit committee and leverage are statistically insignificant, whereas board size and director's remuneration are statistically significant.

\section{DISCUSSION}

Several researches have been conducted to explore the association of corporate governance and financial leverage with the firm's performance. This research observes the association that exists between Textile Company's performance through corporate governance (board size, audit committee member, director's remuneration and financial leverage).

\subsection{H1: Association amongst board size and firm performance is significant.}

The study aimed to determine if the board size influences the firm's performance. The hypothesis was established based on previous literature and consistent with the resource dependency theory. The board size is a very important element in corporate governance.

It has been found by several researchers that the board size is a positively and statistically significant to the total debt ratio. This finding is steady with the resource dependency theory recommending that organizations with the huge board have a greater capacity to raise assets from outer bases to improve the worth of the companies. Thus, findings 
DOI: 10.14807/ijmp.v12i1.773

may reveal the idea of the situation wherein Pakistani firms work whereby huge boards fill in as a method for acquiring support from the environment. In addition, banks and improvement financial firms additionally feel sure while ranging loans to firms with huge board size (Anderson et al., 2004; Abor, 2007; Bokpin \& Arko, 2009; Kyereboah-Coleman \& Biekpe, 2006).

Coles et al., (2008) contends that the effect of board size on execution will contrast for various kinds of firms. Specifically, for organization that are enormous, old and have huge debt, increase board size might be an ideal worth expanding result. Interestingly, for companies with high R\&D and changeability in execution, little board size might be ideal. As per Adams furthermore, Adams and Mehran, (2003) a greater board can successfully observe the activities of the management and gives better aptitude. Alternately, Lipton and Lorsch, (1992) supports that a huge size of boards are less successful contrasted with little board size since certain executives directors may free-ride on the endeavors of others. It has been demonstrated that a positive significant relationship amongst board size and total debt ratio (Kyereboah-coleman \& Biekpe, 2006).

The outcomes of this research validate the association between board size and firms performance. It has been analyzed by examining that there is a positive significant association amongst board size and firms performance. According to the hypothesis we tested, there's a strong positive relationship between board size and firms performance which is statistically significant. Board size plays an active role in corporate governance for the organization. Hence, considering the secondary literature and analyzing the outcomes of this study, it is noticed that large or small board size depends on the company to a company that improves the firm's performance.

\subsection{H2: Association amongst the director's remuneration and organization performance is significant.}

The study aimed to determine if the director's remuneration influences organization performance. The hypothesis was developed based on previous literature and studies. To examine the second goal, the outcomes have shown that there is a positive significant association amongst the director's remuneration on the performance of the textile firm of Pakistan.

Main, (1992) explored that statistically significant positive connection amongst the top director's remuneration and returns to investors. Furthermore Main, (1992) also examined a 
positive and significant relationship amongst board compensation and organization performance. In contrast, Abdullah, (2006) examined a negative significant connection between return on assets and director's pay in Malaysian troubled firms. John and Qian, (2003) examined the association amongst the top management pay and structure and the mix of external issues by the organizations. They explored a negative relationship with the director's pay affectability. In contrast, Wen et al., (2002) discovered a negative insignificant relationship between the director's remuneration and capital structure.

Therefore, considering the secondary literature and evaluating the outcomes of this study, it can be recommended that attractive director's remuneration is to improve the firm's performance. Director's pay should be sufficient enough to pull in and hold the directors who have the capability required to deal with the organization effectively and that the framework of the remuneration and benefits for the directors ought to be attached to the corporate performance.

\subsection{H3: There is a significant association amongst the audit committee and the company's efficiency}

The study aimed to determine if the audit committee effects organization performance. The hypothesis was developed based on previous literature and agency theory. To examine the third goal, the outcomes have shown an insignificant association amongst the audit committee and performance of the textile firm of Pakistan.

Previous studies state that there is a positive association amongst audit committees and board monitoring and observing. Gillan and Starks, (2003) propose that the expense acquired by the agency theory is diminished when an audit committee exists between the top directors of a firm. According to Beasley, (1996); Carcello and Neal, (2003) an audit committee is the best help for outside evaluators. Also, Carcello and Neal, (2003) accept that the existence of an independent audit committee firmly impacts corporate audit charges. In view of Ali Shah et al., (2009) the more audit committee independent is, the more excellent the accounting reporting is and the more in the expansion in corporate audit charges.

Conversely, Ismail et al., (2008) explored that there is a negative association amongst the organization's excellence of financial related activities and the audit committee. Committees, (1999) recommends with Abbott et al., (2004) that most of financial activities error are diminished within the existence of audit committee, as their monitoring reduces the performance in terms profitability of happenings of issues during financial activities. Dechow 
DOI: 10.14807/ijmp.v12i1.773

et al., (1996) and Beasley et al., (2000) observed the misrepresentation that happened in various organizations, and the outcomes demonstrated that organizations having less audit committee members indicated a higher propensity for misrepresentation event. It has been analyzed in their study that organizations experiencing financial misfortunes, Carcello and Neal, (2003) explored that the recurrence of going concern views isn't influenced by the existence of independent audit committee members.

Hence, considering the secondary literature and analyzing the outcomes of this study, it can be recommended that there should be more audit committee members who should be accountable for all financial reporting of the company. When there are more members of the audit committee there will be less chances of financial fraud.

\subsection{H4: Relationship amongst financial leverage and the company's performance is significant.}

The study aimed to determine if the audit committee effects organization performance. The hypothesis was developed based on previous literature and studies. To examine the fourth goal, the outcomes have shown an insignificant association amongst the financial leverage and performance of the textile firm of Pakistan.

According to Abdullah, (2006), there is a negative association between the financial leverage an organization's performance. A researcher also indicated that enhances the degree of financial leverage can make an adverse effect on the importance of firms and move liquidation. Bokpin and Arko, (2009) revealed an insignificant and positive amongst board independence and the debt ratio.

Kyereboah-coleman and Biekpe, (2006) have indicated that financial leverage is positively associated with the extent of outside directors in the board yet the association is statistically insignificant. Sheikh and Wang, (2012) examined a positive insignificant relationship amongst the level of shareholders on the company's board and the debt ratio. Similarly, a researcher analyzed a positive insignificant association amongst board size and leverage (Wen et al., 2002).

Therefore, considering the secondary literature and analyzing the outcomes of this study, it has been noticed that financial leverage is statistically insignificant associated with the firm's performance.

\section{CONCLUSION}


DOI: 10.14807/ijmp.v12i1.773

Overall findings indicate that board size, audit committee, director's remuneration is positively correlated with the firm's performance ROA and ROE, on the other side financial leverage are negatively correlated with the performance of the textile sector of Pakistan. Audit committee and leverage are statistically insignificant, whereas, board size and director's remuneration are statistically significant. Board size plays an active role in corporate governance for the organization.

Hence, considering the secondary literature and analyzing the first hypothesis, it is noticed that large or small board size depends on company to a company that improves the firm's performance and it shows the significant relationship amongst board size and firms performance. While testing the second hypothesis and considering the secondary literature, it can be recommended that attractive director's remuneration is to improve the firm's performance.

Director's pay should be sufficient enough to retain and pull in the directors who have the capability required to deal with the organization effectively and that the framework of the remuneration and benefits for the directors ought to be attached to the corporate performance. While testing the third hypothesis, it has been examined that there was an insignificant association amongst the audit committee and firms performance it is maybe there was less number of audit committee members and they were not accountable for all financial reporting of the company.

When there are more members of the audit committee there will be less chances of financial fraud. Finally, the fourth hypothesis showed an insignificant association between financial leverage and the company's performance. This is also observed that if the corporate governance principles implement properly then companies achieve their objectives successfully.

\section{LIMITATION}

The sample size of this study was small and this research is limited to the textile sector of Pakistan, the sample size could be increased which impact on statistics as there are various textile companies that are listed in PSX. Future researchers may have included more determinants of corporate governance such as women's role on board, board meeting, family ownership structure, etc.

Further studies could compare the results obtained in Pakistan with other developing and developed countries data to describe how better corporate governance implemented in 
different organizations. Keeping in view the current condition of Pakistan the research can also be conducted on other sector firms that are listed in the Pakistan Stock Exchange to examine the corporate governance on organization performance.

\section{REFERENCES}

Abbott, L. J., Parker, S., \& Peters, G. F. (2004). Audit committee characteristics and restatements. Auditing: A Journal of Practice \& Theory, 23(1), 69-87.

Abdullah, S. N. (2006). Directors' remuneration, firm's performance and corporate governance in Malaysia among distressed companies. Corporate Governance: The International Journal of Business in Society.

Abor, J. (2007). Corporate governance and financing decisions of Ghanaian listed firms. Corporate Governance: The International Journal of Business in Society.

Achchuthan, S., \& Rajendran, K. (2013). Corporate governance practices and working capital management efficiency: Special reference to listed manufacturing companies in Sri Lanka.

Adams, R. B., \& Mehran, H. (2003). Is corporate governance different for bank holding companies? Available at SSRN 387561.

Ali Shah, S. Z., Butt, S. A., \& Hassan, A. (2009). Corporate governance and earnings management an empirical evidence form Pakistani listed companies. European Journal of Scientific Research, 26(4), 624-638.

Anderson, R. C., Mansi, S. A., \& Reeb, D. M. (2004). Board characteristics, accounting report integrity, and the cost of debt. Journal of Accounting and Economics, 37(3), 315342.

Beasley, M. S. (1996). An empirical analysis of the relation between the board of director composition and financial statement fraud. Accounting Review, 443-465.

Beasley, M. S., Carcello, J. V., Hermanson, D. R., \& Lapides, P. D. (2000). Fraudulent financial reporting: Consideration of industry traits and corporate governance mechanisms. Accounting Horizons, 14(4), 441-454.

Berger, P. G., Ofek, E., \& Yermack, D. L. (1997). Managerial entrenchment and capital structure decisions. The Journal of Finance, 52(4), 1411-1438.

Bokpin, G. A., \& Arko, A. C. (2009a). Ownership structure, corporate governance and capital structure decisions of firms. Studies in Economics and Finance.

Bokpin, G. A., \& Arko, A. C. (2009b). Ownership structure, corporate governance and capital structure decisions of firms. Studies in Economics and Finance.

Carcello, J. V., \& Neal, T. L. (2003). Audit committee characteristics and auditor dismissals following "new" going-concern reports. The Accounting Review, 78(1), 95-117.

Coffee Jr, J. C. (2005). A theory of corporate scandals: Why the USA and Europe differ. Oxford Review of Economic Policy, 21(2), 198-211.

Coles, J. L., Daniel, N. D., \& Naveen, L. (2008). Boards: Does one size fit all? Journal of Financial Economics, 87(2), 329-356.

Committees, B. R. C. on I. the E. of C. A. (1999). Report and recommendations of the Blue Ribbon Committee on improving the effectiveness of corporate audit committees. The 
DOI: 10.14807/ijmp.v12i1.773

Business Lawyer, 1067-1095.

Dalton, C. M., \& Dalton, D. R. (2005). Boards of directors: Utilizing empirical evidence in developing practical prescriptions. British Journal of Management, 16, S91-S97.

Dechow, P. M., Sloan, R. G., \& Sweeney, A. P. (1996). Causes and consequences of earnings manipulation: An analysis of firms subject to enforcement actions by the SEC.

Contemporary Accounting Research, 13(1), 1-36.

Gill, A., \& Mathur, N. (2011). The impact of board size, CEO duality, and corporate liquidity on the profitability of Canadian service firms. Journal of Applied Finance and Banking, 1(3), 83.

Gillan, S., \& Starks, L. T. (2003). Corporate governance, corporate ownership, and the role of institutional investors: A global perspective. Journal of Applied Finance, 13(2).

Guest, P. M. (2009). The impact of board size on firm performance: Evidence from the UK. The European Journal of Finance, 15(4), 385-404.

Herdan, A., \& Szczepańska, K. (2011). Directors Remuneration and Companies' Performance the Comparison of Listed Companies in Poland and UK. Foundations of Management, 3(2), 41-54.

Ismail, S., Aliahmed, H. J., Nassir, A. M., \& Hamid, M. A. A. (2008). Why Malaysian second board companies switch auditors: Evidence of Bursa Malaysia. International Research Journal of Finance and Economics, 13(13), 123-130.

Jensen, M. C., \& Meckling, W. H. (1976). Theory of the firm: Managerial behavior, agency costs and ownership structure. Journal of Financial Economics, 3(4), 305-360.

John, K., \& Qian, Y. (2003). Incentive features in CEO compensation in the banking industry. Economic Policy Review, 9(1).

Kalbers, L. P., \& Fogarty, T. J. (1993). Audit committee effectiveness: An empirical investigation of the contribution of power. Auditing, 12(1), 24.

Khatab, H., Masood, M., Zaman, K., Saleem, S., \& Saeed, B. (2011). Corporate governance and firm performance: A case study of Karachi stock market. International Journal of Trade, Economics and Finance, 2(1), 39.

Kyereboah-coleman, A., \& Biekpe, N. (2006). Corporate governance and financing choices of firms: A panel data analysis. South African Journal of Economics, 74(4), 670-681.

Lipton, M., \& Lorsch, J. W. (1992). A modest proposal for improved corporate governance. The Business Lawyer, 59-77.

Main, B. (1992). Top executive pay and company performance. University of Edinburgh Mimeograph.

Main, B. G. (1993). Pay in the Boardroom: Practices and procedures. Personnel Review, 22(7), 3-14.

Mehran, H. (1992). Executive incentive plans, corporate control, and capital structure. Journal of Financial and Quantitative Analysis, 27(4), 539-560.

Nahar Abdullah, S. (2006a). Directors' remuneration, firm’s performance and corporate governance in Malaysia among distressed companies. Corporate Governance: The International Journal of Business in Society, 6(2), 162-174.

Nur’ainy, R., Nurcahyo, B., Kurniasih, S. A., \& Sugiharti, B. (2013). Implementation of good 
DOI: 10.14807/ijmp.v12i1.773

corporate governance and its impact on corporate performance: The mediation role of firm size (Empirical study from Indonesia). Global Business and Management Research, 5(2/3), 91.

Patro, S., Lehn, K., \& Zhao, M. (2003). Determinants of the size and structure of corporate boards: 1935-2000. Financial Management, 38, 2009.

Raheja, C. G. (2005). Determinants of board size and composition: A theory of corporate boards. Journal of Financial and Quantitative Analysis, 40(2), 283-306.

Rashid, K. (2008). A comparison of corporate governance and firm performance in developing (Malaysia) and developed (Australia) financial markets. Victoria University.

Sheikh, N. A., \& Wang, Z. (2012). Effects of corporate governance on capital structure: Empirical evidence from Pakistan. Corporate Governance: The International Journal of Business in Society.

Tahir, S. H., Rehman, R., \& Rehman, N. U. (2014). Corporate governance and financial leverage impact on the value of firms (Evidence from Textile Sector Pakistani Listed Companies). The International Journal's Research of Economics and Business Studies, 3(6), 25-33.

Todorovic, I. (2013). Impact of corporate governance on performance of companies. Montenegrin Journal of Economics, 9(2), 47.

Wen, Y., Rwegasira, K., \& Bilderbeek, J. (2002a). Corporate governance and capital structure decisions of the Chinese listed firms. Corporate Governance: An International Review, 10(2), 75-83.

Wen, Y., Rwegasira, K., \& Bilderbeek, J. (2002b). Corporate governance and capital structure decisions of the Chinese listed firms. Corporate Governance: An International Review, 10(2), 75-83.

Williamson, O. E. (1985). The economic institutions of capitalism: Firms, markets, relational contracting. Free Press. 